\title{
ACCOUNTING FOR BANK DEPOSITS, TRUST FINANCING (MUDARABAH) AND TAX FOR THE POOR AND NEEDY (ZAKAT) OF ISLAMIC FINANCIAL INSTITUTIONS: DISTINCTIONS"
}

\section{Khusan S. UMAROV}

IPT LTD (PAYMO), Moscow, Russian Federation

khusan0000@gmail.com

https://orcid.org/0000-0001-9674-9873

\section{Article history:}

Article No. 543/2019

Received 6 August 2019

Received in revised form 14 October 2019

Accepted 8 November 2019

Available online

25 December 2019

\section{JEL classification: M41}

Keywords: Islamic accounting, reporting, AAOIFI, standards, accounting records

\begin{abstract}
Subject The article deals with Islamic financial mechanisms and their recognition in accounting records of Islamic financial institutions.

Objectives The study unfolds the specifics of bank deposits, trust financing and tax paid to the poor under the Islamic accounting model.

Methods The study involves methods of comparative analysis, systematization, classification, analogy and comparison.

Results I examine financial mechanisms of Islamic institutions and give examples how the mechanisms are recognized in accounting books. I also classified their types and emphasized their distinctions. Islamic banks accrue no interests on savings. Financial instruments are based on principles of profit and loss sharing. In addition to income tax, Islamic financial institutions pay the religious tax. The article presents AAOIFI standards governing the above accounts and reveals accounting records of capital proceeds and/or repayment, accrual of profit and/or loss, informs on the requirement to prepare a special report, which is published along with other traditional reports. The article also gives a detailed account of a special tax to the poor (Zakat), terms of its collection and payment, rules and method for its calculation, who is entitled to the payments and the reasons for doing so, measurement of assets and liabilities that are subject to the tax.

Conclusions and Relevance The Islamic accounting model provides for three types of on-call deposits, i.e. Wadiah, Amanah and Qard Hasan. They are recorded in accounting books as if it were the conventional accounting model. Investment deposits (Mudarabah) are different. They do not provide for any return. The return solely depends on the outcome of a project. Accounts are based on profit and loss sharing principles and resemble venture capital existing in the modern economic practice.
\end{abstract}

(C) Publishing house FINANCE and CREDIT, 2019

The editor-in-charge of this article was Irina M. Vechkanova

The authorized translation by Irina M. Vechkanova

Please cite this article as: Umarov Kh.S. Accounting for Bank Deposits, Trust Financing (Mudarabah) and Tax for the Poor and Needy (Zakat) of Islamic Financial Institutions: Distinctions. Digest Finance, 2019, vol. 24, iss. 4, pp. 368-378.

https://doi.org/10.24891/df.24.4.368

\section{Introduction}

The way Islamic financial institutions (IFI) account for specific transactions reveals the most

\footnotetext{
"For the source article, please refer to: Умаров Х.С. Особенности учета банковских вкладов, доверительного финансирования (мудараба) и налога в пользу бедных и нуждающихся (закят) исламских финансовых институтов // Международный бухгалтерский учет. 2019. Т. 22, № 11 . C. 1256-1270. URL: https://doi.org/10.24891/ia.22.11.1256
}

outstanding distinction of the Islamic accounting model.

Accounting for Bank Deposits. Both the Russian and Islamic banks offer retail and corporate services and open three types of accounts current, savings and investment ones [1, p. 25].

In Islamic banks, current accounts mainly resemble those in the Russian banks. In most 
cases, banks grant interest-free loans (Qard Hasan) and open accounts for customers to hold their funds on terms of safe keeping (Amanah).

Interest-free loans Qard Hasan represent contracts stipulating that the bank grants cash to its customers without obliging them to pay interests in return (short-term finance). The customer is allowed to repay the debt by installments, if so contractually agreed. Banks do not get earnings on such contracts but perform their social mission of providing aid to those in need. Moreover, banks may set up their own charity pool with shareholders' funds and/or capital of investment account holders. The latter case is possible if the depositor (a holder of an investment account) instructs the bank to remit respective funds for charity [2]. Accounting entries on such transactions are given in Table 1.

Amanah $^{1}$, or safe custody, constitutes contracts for safe custody that permits the bank to handle the customer's funds upon his/her consent only on a fee basis. As a rule, the bank cannot use the funds for its own purposes, that is, being bound to maintain a 100-percent reserve for such accounts [3, p. 126]. In case of losses the bank is not deemed liable, since it has fulfilled its obligations. Amanah accounts work like current accounts (or on-call accounts) in the Russian banking practice. Banks account for Amanah deposits as liabilities, since they guarantee to keep the funds safe in the account and return them to the depositor as soon as he/she demands so. Accounting entries on Amanah accounts are presented in Table 2 .

Islamic savings account essentially differ from those in the Russian banking. Opening a savings account, the customer expects to get some earnings. However, such earnings cannot be provided as a fixed interest on the deposit amount (riba), being a portion of profit an Islamic bank derives using the customer's funds. Islamic banks accept funds to keep them in savings accounts under Wadiah terms. Wadiah is a contract for safe keeping, which is similar to Amanah. However, it provides for customers' permits to use their deposits. Banks also undertake to keep funds safe and return them to customers as they demand so.
Accounting entries on such transactions are showed in Table 3.

We also should focus on Mudarabah, or trust financing. As opposed to the Russian banks, Islamic ones tend to invest in their customers, rather than credit them. Thus, the bank contributes funds depositors keep in investment accounts to various projects on profit-and-loss principles (PLS). Profit and losses are shared between the bank and a depositor in an agreed proportion. Hence, profit the depositor gets completely depends on the outcome of an investment project [4, p. 18].

Islamic banks often use Mudarabah, or trust finance contracts, to formalize their relationships with holders of investment accounts. Mudarabah is a two-party agreement, where one party provides funds (a customer) and the other one (a bank) manages the funds, investing them in various projects. The financial trustee (a bank) is called Mudarib. It manages a business project. Mudarabah stipulates ratios for distributing profit between the bank and the investor, as well as the bank's guarantees to reimburse losses if it fails to perform properly or violates terms of the contract. There is an identical financing technique in the Russian economy. This is limited partnership, or trust finance [5, p. 390]. Generally, an Islamic bank uses funds it collects as investment deposits to finance short- and midterm projects (for example, in trade). Investment accounts do not guarantee the payback. Earnings on such accounts are usually comparable with interests that depositors may get in the Russian banks.

Accounting for investment accounts is stipulated in Financial Accounting Standard No. 6 AAOIFI - Equity of Investment Account Holders (effective since January 1, 1999) and Financial Accounting Standard No. 3 AAOIFI - Mudarabah (effective since January 1, 1998). They articulate accounting rules for deposits the bank accepts for investing purposes. The standards provide for two types of investment accounts:

1) unrestricted investment accounts, i.e. the bank can use funds at it thinks fit without restrictions;

\footnotetext{
${ }^{1}$ Arabic - honesty, reliability
} 
2) restricted investment accounts, i.e. the bank uses funds held in investment accounts as the depositor allows it to $\mathrm{do}^{2}$.

The bank recognizes unrestricted investment accounts as soon as it accepts cash from a depositor. When it is contractually agreed that the bank will not invest the depositor's funds until a certain date, the funds are posted to current accounts and subsequently transferred to unrestricted investment accounts on the investment date. Equity of unrestricted account holders is measured as much as the bank accepts under the contract. As of the end of the period, equity is recognized at its carrying amount.

Return on investment, which is secured with equity of account holders, depends solely on the outcome of a business project. It should be distributed among stakeholders in pre-agreed ratios. The bank does not accrue any profit before it receives a supporting documents from the business project manager. If the bank does not receive the total amount due from the business project manager, the remaining amount is carried in the statement of financial position as accounts receivable.

As set forth in Mudarabah, loss from investment is completely borne by the bank's customer (equity holder). However, if the loss results from illegal performance or negligence of the bank, the loss shall be borne by the bank on the basis of a report of the Sharia supervisory board of the bank [6, p. 9].

Equity of unrestricted account holders is presented in the statement of financial position of the Islamic bank. It is showed in a separate section between Equity and Liabilities.

Normally, traditional banks recognize bank deposits as liabilities. However, Islamic banks post unrestricted investment accounts under Mudarabah to equity. Holders of unrestricted investment accounts, to some extent, can be considered quasi-shareholders.

As soon as the Islamic bank accepts the depositor's equity (a holder of an unrestricted

\footnotetext{
${ }^{2}$ Accounting, Auditing and Governance Standards for Islamic

${ }^{2}$ Accounting, Auditing and Governance Standards for Islamic
Financial Institutions. Manama, Bahrain, AAOIFI, 2010. 1432H 809 P.
}

Х.С. Умаров / Дайджест-Финансы, 2019, т. 24, вып. 4, стр. 368-378 investment account), it invests it in some project. Such investment is accounted as assets (financial investment) in the statement of financial position. If a project ends up in profit, the bank earns more than it invested, that is profit plus equity. Subsequently, the bank remits an amount of invested equity and a respective portion of profit to the depositor.

Table 4 shows accounting entries an Islamic bank makes to account for unrestricted investment accounts in case of a profitable project.

There are two scenarios of an unprofitable investment project:

1) the loss equals the invested equity;

2 ) the loss is less than the invested equity.

Mudarabah limits the liability of an investor to the invested equity.

When the loss equals the invested capital, the bank makes an accounting entry on the loss to debit the profit and loss account and credit the financial investment account. Then the loss is posted to the Mudarabah account. Thus, the Mudarabah account is closed [7, p. 105]. Table 5 shows such accounting entries.

When the loss is less than the invested equity, the bank should get the remaining portion of equity back (in excess of the loss) and return the amount to the customer. Table 6 shows such accounting entries.

There are some difficulties in accounting for unrestricted investment accounts opened on Mudarabah terms. Islamic banks act as intermediaries with two types of investors - those ones who invest equity in the very financial company as shareholders, without having any vote in its management, and those ones who simply place their money in unrestricted investment accounts under Mudarabah. The accountant assesses profit (or loss) earmarked for holders of investment accounts and profit paid as dividends to shareholders [8, p. 110]. The loss some incur turns into profit for the others. Hence, it is difficult to extract relevant information about types of the bank's activities related to investing depositors and shareholders. In this respect, I believe, it would be reasonable to apply the 
Activity-Based Costing method (ABC) p. 940].

Equity of restricted investment account holders is measured as much as cash the bank accepts from a depositor. Assets and liabilities associated with such equity shall be considered separately from the remaining assets and liabilities of the bank. If the bank has more than one type of restricted investment accounts, amounts per each type should be accounted separately. At the end of the reporting period, equity of limited investment account holders is measured at the carrying amount. Restricted investment accounts under Mudarabah are considered as off-balance sheet accounts, since the bank cooperates with unusual investors on special terms. A holder of such an account can restrict the scope of transactions that the bank may make, or amend terms of investment, etc. $[10$, p. 135]. For example, the holder may instruct the bank to carry his funds separately from other assets of the bank when the bank invests in the same project, or prohibit to invest in presumably unprofitable deals.

Information on the equity of restricted investment account holders is presented in the statement of changes in restricted investment. The statement is a part of financial statements $[11$, p. 115]. The statement of changes in restricted investment discloses each investment portfolio and sources of finance:

- opening balances of restricted Mudarabah accounts, amounts the bank receives from revaluation of restricted investment to match the current values;

- the number of investment units in each investment portfolio and the value of each investment unit as of the beginning of the period;

- deposits or investment units throughout the analyzable period;

- purposes of an investment portfolio;

- a share of the Islamic bank in an investment portfolio under Mudarabah contracts or a fixed fee paid to the bank as an investment agent (equity manager);
- gains (losses) from restricted investment throughout the analyzable period;

- the number of investment units in each investment portfolio and the value of each investment unit as of the end of the period.

Notes to the statement of changes in restricted investment inform of the nature of relationships between the Islamic bank and holders of restricted Mudarabah accounts.

Any bank is always exposed to the risk of bad or doubtful debts. Therefore, Islamic banks make two types of reserves - general and specialpurpose ones. General reserves are intended for possible losses, which may arise from accounts receivable, financial and investment assets. Special-purpose reserves are used to write down doubtful loans, which were individually evaluated and subsequently recognized as bad or doubtful [12, p. 219].

Suppose we study the assessment, accounting and recognition of tax for the poor and the needy (Zakat) in financial statements. Zakat, an annual tax, is one of the pillars in the Islamic financial system. It serves for alleviating social tensions by reallocating the wealth. Zakat is levied so that money would always circulate, without being accumulated by a small number of people. Zakat is paid once a year in cash and in kind [13, p. 445]. Zakat is one of the five pillars in Islam. Therefore, it is obligatory for all Muslims, though, in fact, it is supposed to be voluntary, except for several countries. Nowadays, Zakat is levied in Libya, Pakistan, Sudan, Saudi Arabia, Yemen and most states of Malaysia [14, p. 37].

There are five rules for charging Zakat.

1. Zakat applies to Muslims.

2. Zakat is paid by free Muslims.

3. The value of the taxable property should correspond with the taxable minimum (Nisab), which equals 85 grams of gold. The property below the above value is exempt of Zakat.

4. The property subject to Zakat should be owned by an individual or a legal entity on a free-hold basis. 
5. An individual or a legal entity should own the property for a year.

Islam envisages eight classes of Zakat recipients. These are the poor, the needy, Zakat administrators, those whose hearts are to be reconciled, debt-ridden, those in bondage (this class benefited from Zakat on the onset of Islam, since Zakat was paid to release people from captivity), travelers and those following the way of Allah. Money collected from Zakat can be allocated for the construction of social facilities (schools, hospitals, mosques, etc.) and the development of social infrastructure used in everyday life [15, p. 110].

The payment of Zakat does not mean that a taxpayer is eligible for any tax breaks with respect to other taxes or reduced tax burden. Zakat is a specific tax that does not depend on other taxes paid and vice versa. To say it in other words, Zakat is paid on particular principles, which do not depend on the fiscal system of the State, thereby actually increasing the tax burden of an enterprise.

In 1984, the First Zakat Conference was held in Kuwait, where participants decided that all Islamic financial institutions were to pay Zakat. Islamic financial institutions pay Zakat in three cases:

1) national laws requires to pay Zakat;

2) corporate by-laws recommends paying Zakat;

3) shareholders advice to do so. In 1999, AAOIFI released the Standard on Zakat (Financial Accounting Standard No. 9), which governs various aspects of Zakat accounting in Islamic banks.

The way Zakat is assessed directly influences accounting policies and practice. Preparing financial statements, accountants intend to not only provide information to interested users, but also measure the property subject to Zakat [16, p. 32].

As for Islamic banks, the taxable base subject to Zakat usually includes financial assets, cash, accounts receivable and assets held for sale within a year. I should mention various opinions on the formation of the taxable base subject to Zakat. The main disputable point concerns the deduction of accounts payable from the taxable base. If accounts payable should be subtracted from the taxable base, which ones specifically should be taken out? In the mean time, as set forth in Financial Accounting Standard No. 9 AAOIFI, only current accounts payable should be subtracted from the taxable base subject to Zakat.

Financial Accounting Standard No. 9 AAOIFI provides for two methods of Zakat assessment, i.e. the net asset method and net investment method [17, p. 25].

The net asset method uses the formula below to assess Zakat:

$Z_{N A}=M_{C}+A R_{R}+A_{S}+A_{F R}-A_{P C}-P_{M S}-C_{S O}-$ $-D-C_{N P}$

where

$Z_{N A}$ stands for Zakat assessed through net assets;

$M_{C}$ is cash;

$A R_{R}$ means accounts receivable net of reserve for doubtful debts;

$A_{S}$ means assets purchased for sale (for example, inventories, marketable securities, real estate, etc.);

$A_{F R}$ means financial assets (for example, Mudarabah, Musharaka, Salam, Istisna) net of a provision for impairment and default;

$A_{P C}$ means current accounts payable;

$P_{M S}$ means a portfolio of minority shares;

$C_{S O}$ means State-owned capital;

$D$ means funds for donations;

$C_{N P}$ means capital which is not intended for profit-making (capital owned inter alia by nonprofit organizations).

The following formula measures Zakat through net investment:

$Z_{N I}=C_{S}+R+E_{R}+P_{N}+L B-\left(F A_{N}+I+L S_{U N}\right)$,

where

$Z_{N I}$ is Zakat through net investment; 
$C_{S}$ is capital paid up/contributed (share), i.e. the - the method they use to assess Zakat; paid portion of shares issued by IFI;

$R$ means economic reserves;

$E_{R}$ means retained earnings for the previous period;

$P_{N}$ is net profit;

$L B$ means liabilities that are not due within a year;

$F A_{N}$ means net fixed assets;

$I$ is investment intended for sale (for example, real estate for rent);

$L S_{U N}$ is uncovered loss.

Assets are measured at possible net selling price (as of the Zakat payment date), rather than at the historical cost. Hence, this engenders revaluation funds, which shall be disclosed in notes to financial statements [18, p. 336].

As mentioned above, Islamic banks may undertake to collect Zakat on behalf of their customers, shareholders or owners of unrestricted investment accounts. Table 7 shows accounting entries on the accrual and payment of Zakat.

As required in Financial Accounting Standard No. 9 AAOIFI - Zakat, banks shall disclose the following information in notes to financial statements:

- the resolution of the Sharia Board of the Islamic bank on Zakat issues, which were omitted in the said standard;

- Zakat assessment restrictions imposed by the Sharia Board of the bank. For example, when the net investment method is used, total fixed assets and investment, which are not intended for sale, shall not exceed total capital paid up and capital buffer.

Islamic financial institutions must pay Zakat. Liabilities to collect and pay Zakat are carried in a special account showing the responsibility of such institutions for Zakat administration [19, p. 56]. As per Financial Accounting Standard No. 9 AAOIFI - Zakat, Zakat expenses shall be attributed to other expenses. If Zakat is accrued but not yet paid as of the date of the statement of financial position, the tax shall be posted to liabilities of the bank.

As a conclusion, it is worth mentioning that Islamic financial mechanisms are relevant to the global financial system today. Most of them are supposed and actually used for partnership and a common good as opposed to interest-bearing relationships offered by the Western credit institutions. Zakat ensures the circulation of money and allocation of wealth among the poor and the rich, thus reducing the economic disparity of people. 
Table 1

Accounting recognition of current account transactions (Qard Hasan)

Qard Hasan on a repayment basis

Remittance of cash to the beneficiary of interest-free Qard Hasan

Debit

Share capital/equity of investment account holders

Credit

Cash account

Debit

Accounts receivable for Qard Hasan

Credit

Current accounts under Qard Hasan

Cash repaid by the beneficiary of interest-free Qard Hasan

\begin{tabular}{ll} 
Debit & Current accounts Qard Hasan \\
\hline Credit & Accounts receivable for Qard Hasan \\
\hline Debit & Cash account \\
\hline Credit & Share capital/equity of investment account holders
\end{tabular}

Qard Hasan for charity

Remittance of cash to the beneficiary

Debit

Credit

Other expenses

Charity account

Debit Share capital/equity of investment account holders

Credit

Cash account

Source: Authoring

Table 2

Accounting recognition of current account transactions (Amanah)

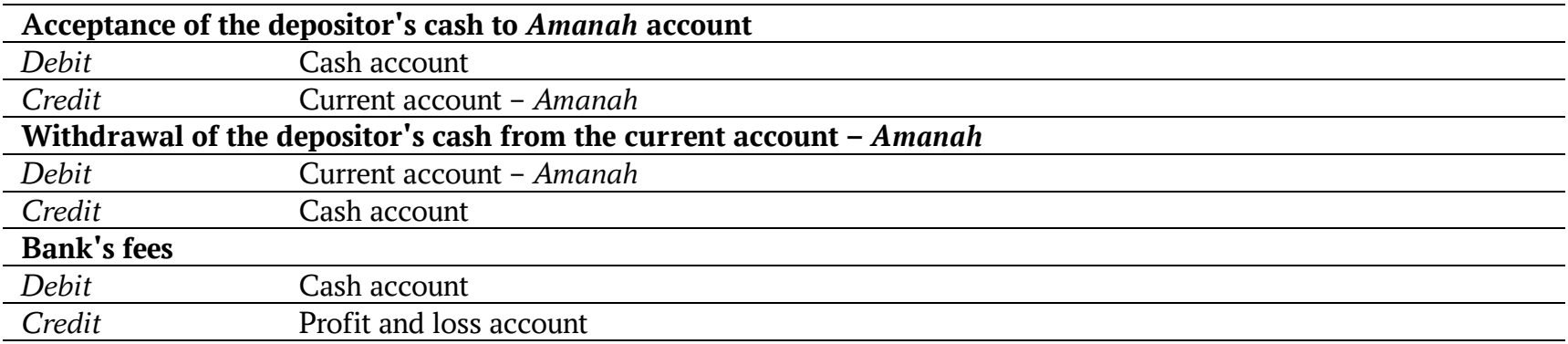

Source: Authoring

Table 3

Accounting recognition of saving account transactions (Wadiah)

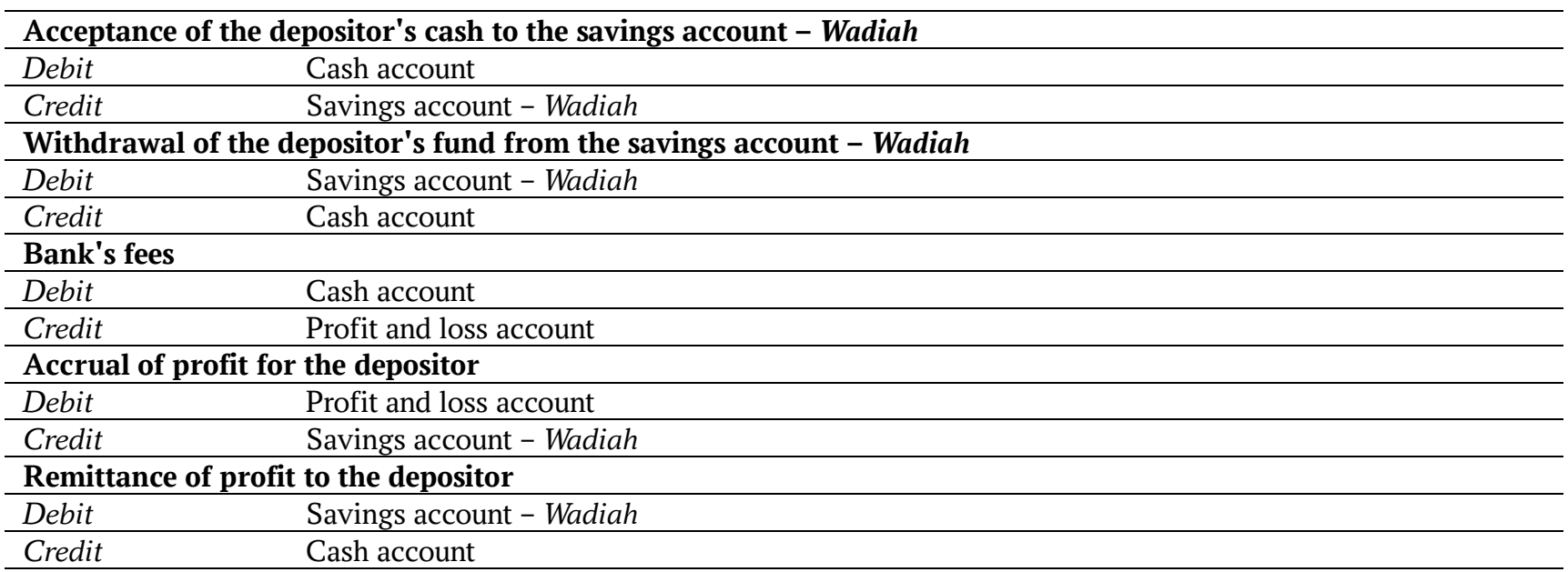

Source: Authoring 
Table 4

Accounting recognition of transactions via unlimited investment accounts (Mudarabah) in case of profitable projects

The customer's deposit with the bank

\begin{tabular}{|c|c|}
\hline Debit & Cash account \\
\hline Credit & Mudarabah account \\
\hline \multicolumn{2}{|c|}{ Recognition of capital invested in a business project } \\
\hline Debit & Financial investment \\
\hline Credit & Cash account \\
\hline \multicolumn{2}{|c|}{ Accrual of profit from a business project (against a supporting document) } \\
\hline Debit & Accounts receivable \\
\hline Credit & Profit and loss account \\
\hline \multicolumn{2}{|c|}{ Profit from a business project } \\
\hline Debit & Cash account \\
\hline Credit & Account receivable \\
\hline \multicolumn{2}{|c|}{ Invested capital deposited with the bank (upon the outcome of a business project) } \\
\hline Debit & Cash account \\
\hline Credit & Financial investment \\
\hline \multicolumn{2}{|c|}{ Accrual of profit due to the customer of the bank } \\
\hline Debit & Profit and loss account \\
\hline Credit & Mudarabah account \\
\hline \multicolumn{2}{|c|}{ Remittance of invested capital and profit due to the customer of the bank } \\
\hline Debit & Mudarabah account \\
\hline Credit & Cash account \\
\hline
\end{tabular}

Source: Authoring

Table 5

Accounting recognition of transactions via unrestricted investment accounts (Mudarabah) in case of unprofitable projects (loss and investment are equal)

The customer's deposit with the bank

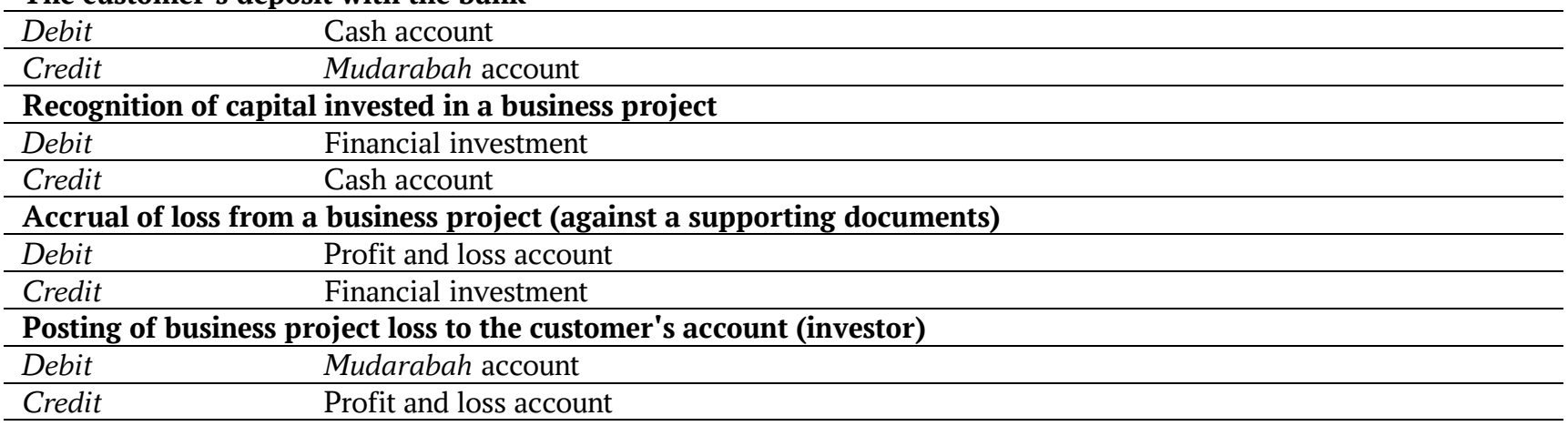

Source: Authoring 
Table 6

Accounting recognition of transactions via unrestricted investment accounts (Mudarabah) in case of unprofitable projects (loss is less than investment)

\begin{tabular}{|c|c|}
\hline The cus & it with the bank \\
\hline Debit & Cash account \\
\hline Credit & Mudarabah account \\
\hline Recogn & invested in a business \\
\hline Debit & Financial investment \\
\hline Credit & Cash account \\
\hline Accrua & business project (agair \\
\hline Debit & Profit and loss account \\
\hline Credit & Financial investment \\
\hline Posting & oject loss to the custom \\
\hline Debit & Mudarabah account \\
\hline Credit & Profit and loss account \\
\hline Deposit & ing invested capital to $t$ \\
\hline Debit & Cash account \\
\hline Credit & Financial investment \\
\hline Remitt: & naining invested capital \\
\hline Debit & Mudarabah account \\
\hline Credit & Cash account \\
\hline
\end{tabular}

Source: Authoring

Table 7

Accounting recognition of Zakat transactions

\begin{tabular}{|c|c|}
\hline \multicolumn{2}{|c|}{ Zakat collected by the bank } \\
\hline Debit & Cash account \\
\hline Credit & Special-purpose account for the collection of Zakat \\
\hline \multicolumn{2}{|c|}{ Accrual of Zakat collected for further payment } \\
\hline Debit & Special-purpose account for the collection of Zakat \\
\hline Credit & Charity settlements \\
\hline \multicolumn{2}{|c|}{ Accrual of Zakat by the bank (out of equity) } \\
\hline Debit & Profit and loss account \\
\hline Credit & Charity settlements \\
\hline \multicolumn{2}{|c|}{ Remittance of Zakat collected } \\
\hline Debit & Charity settlements \\
\hline Credit & Cash account \\
\hline
\end{tabular}

Source: Authoring

\section{Acknowledgments}

I express my deep appreciation to Ekaterina Yu. VORONOVA, Doctor of Economics, Associate Professor, Acting as the Head of the Department for Accounting, Statistics and Audit at the MGIMO-University, for her advice and valuable comments on the article.

\section{References}

1. DiVanna J.A. Understanding Islamic Banking: The Value Proposition that Transcends Cultures. Cambridge University Press, 2008, 174 p.

2. Khamidullina Z.Ch. [The social orientation as a defining feature of Islamic accounting]. Finansovyi biznes $=$ Financial Business, 2016, no. 2, pp. 49-52. (In Russ.)

3. Gordeeva O.E., L'vova N.A. [Islamic financial system]. Vestnik SPbU. Seriya 5: Ekonomika = St. Petersburg University Journal of Economic Studies, 2009, no. 3, pp. 124-133. (In Russ.) 
4. Napier Ch. Other Cultures Other Accounting? Islamic Accounting from Past to Present. 5th Accounting History International Conference. Banff Center, 2007, 34 p.

5. Umarov Kh.S. [Islamic model of accounting as a socio-economic phenomenon]. Mezhdunarodnyi bukhgalterskii uchet = International Accounting, 2017, vol. 20, iss. 7, pp. 385-396. (In Russ.) URL: https://doi.org/10.24891/ia.20.7.385

6. Atmeh M.A., Hadi Ramadan A. A Critique on Accounting for the Mudarabah Contract. Journal of Islamic Accounting and Business Research, 2012, vol. 3, iss. 1, pp. 7-19. URL: https://doi.org/10.1108/17590811211216032

7. Maali B., Napier Ch. Accounting, Religion and Organizational Culture: The Creation of Jordan Islamic Bank. Journal of Islamic Accounting and Business Research, 2010, vol. 1, iss. 2, pp. 92-113. URL: https://doi.org/10.1108/17590811011086705

8. Mervyn K.L. Islam and Accounting. Accounting Forum, 2001, vol. 25, no. 2, pp. 103-127.

9. Voronova E.Yu. [Islamic accounting model: Approaches to the measurement of assets and liabilities]. Ekonomika i predprinimatel'stvo = Journal of Economy and Entrepreneurship, 2016, no. 8, pp. 938-941. (In Russ.)

10. Sivakumar Velayutham. Conventional Accounting vs Islamic Accounting: The Debate Revisited. Journal of Islamic Accounting and Business Research, 2014, vol. 5, iss. 2, pp. 126-141. URL: https://doi.org/10.1108/JIABR-05-2012-0026

11. Altarawneh G., Lucas M. Understanding the Dominance of Western Accounting and Neglect of Islamic Accounting in Islamic Countries. Journal of Islamic Accounting and Business Research, 2012, vol. 3, iss. 2, pp. 99-120. URL: https://doi.org/10.1108/17590811211265920

12. Umarov Kh.S. [Ethical code of the Shariah is institutional principles of the Islamic accounting model]. Sostoyanie i perspektivy razvitiya bukhgalterskogo ucheta i kontrolya $v$ sovremennykh kontseptsiyakh upravleniya: materialy Mezhdunarodnoi nauchnoi konferentsii studentov, aspirantov i molodykh uchenykh [Proc. Sci. Conf. The Current Situation and Future of Accounting and Control as per Modern Management Concepts]. Donestk National University of Economics and Trade named after Mikhail Tugan-Baranovskiy Publ., 2015, pp. 217-220. (In Russ.)

13. Voronova E.Yu. [The role of Zakat (religious tax to the poor) in the Islamic accounting model]. Ekonomika i predprinimatel'stvo = Journal of Economy and Entrepreneurship, 2016, no. 10-1, pp. 444-446. (In Russ.)

14. Bekkin R.I. [Zakat: Taxes or a religious obligation?]. Finansy = Finance, 2008, no. 11, pp. 35-39. (In Russ.)

15. Umarov Kh.S. [Accounting and assessment of Zakat in Islamic financial institutions]. Стан та перспективи розвитку обліку, аналізу, аудиту та контролю в умовах трансформації економіки: Міжнародна науково-практична конференція. Аналітичний центр Нова Економіка, 2014, pp. 109-112. (In Russ.)

16. Voronova E.Yu. [Ethics as a part of the Islamic accounting model]. Auditor, 2016, no. 8, pp. 29-34. (In Russ.)

17. Farah Aida A.N. Roles and Impacts of AAOIFI in Dealing with the Accounting and Disclosure of Zakah and Interest (Riba). Auckland University of Technology, 2009, 78 p. 
18. Voronova E.Yu. [The influence of the religious factor in Islamic accounting model]. Evraziiskii yuridicheskii zhurnal $=$ Eurasian Law Journal, 2016, no. 5, pp. 335-337. (In Russ.)

19. Umarov Kh.S. [On financial reporting in the Islamic insurance companies: AAOIFI Financial Accounting Standard 12]. Strakhovoe delo = Insurance Business, 2013, no. 6, pp. 52-57. (In Russ.)

\section{Conflict-of-interest notification}

I, the author of this article, bindingly and explicitly declare of the partial and total lack of actual or potential conflict of interest with any other third party whatsoever, which may arise as a result of the publication of this article. This statement relates to the study, data collection and interpretation, writing and preparation of the article, and the decision to submit the manuscript for publication. 